\title{
Antioxidant activity assay of white Turi (Sesbania grandiflora (L.) Pers.) extracts using DPPH radical scavenging method
}

\author{
Jamilatur Rohmah* ${ }^{1}$, Ida Agustini Saidi ${ }^{2}$, Chylen Setiyo Rini ${ }^{1}$, Zulfida Ainindiyah Putri \\ Purwanto $^{3}$, Karlia Hedit Tiana ${ }^{3}$, Tri Chahyani Rahmawati Putri ${ }^{3}$ \\ ${ }^{I}$ Department of Medical Laboratory Technology, Faculty of Health Science \\ Universitas Muhammadiyah Sidoarjo \\ Jl. Raya Rame Pilang No.4 Wonoayu, Sidoarjo, East Java, Indonesia, (Pilang Campus) \\ ${ }^{2}$ Department of Agricultural Product Technology, Faculty of Science and Technology \\ Universitas Muhammadiyah Sidoarjo \\ Jl. Taya Gelam 250 Candi, East Java, Indonesia (Gelam Campus) \\ ${ }^{3}$ Postgraduate Program of Medical Laboratory Technology, Faculty of Health Science \\ Universitas Muhammadiyah Sidoarjo \\ Jl. Raya Rame Pilang No.4 Wonoayu, Sidoarjo, East Java, Indonesia, (Pilang Campus)
}

\begin{abstract}
Turi (Sesbania grandiflora (L.) Pers.) is a type of plant belonging to the Fabaceae family that is widespread in Indonesian territory and has the potential as a natural free radical scavenger. The study aimed to compare the antioxidant activity from white Turi (Sesbania grandiflora (L.) Pers.) leaf extracts in various extraction solvents. The determination of antioxidant activity was carried out using the DPPH method with a UV-Vis spectrophotometer. The turi plants used were originated from Mojosari, Mojokerto, East Java, Indonesia. Simplicia turi leaves were macerated in various extraction solvents: ethanol, ethyl acetate, and n-hexane for 24 hours. The extraction results were then subjected to phytochemical and antioxidant activity tests. The result showed that the white turi extract has antioxidant activity with strong activity against DPPH radicals; with n-hexane > ethyl acetate extract > ethanol extract. The $\mathrm{IC}_{50}$ values ethanol,sethyl acetate, and $\mathrm{n}$-hexane extracts of white turi leaves were $33.09 \mathrm{ppm} ; 26.99 \mathrm{ppm}$; and $25.33 \mathrm{ppm}$. The ascorbic acid has an $\mathrm{IC}_{50}$ of $4.93 \mathrm{ppm}$. Based on these results, the white turi plant (leaves) can be one of the natural sources of antioxidants to prevent diseases caused by free radicals.
\end{abstract}

Keywords: antioxidant activity, white turi (Sesbania grandiflora (L.) Pers.) leaves extract, DPPH, various extraction solvents

\footnotetext{
*Corresponding author:

Jamilatur Rohmah

Department of Medical Laboratory Technology, Faculty of Health Science

Universitas Muhammadiyah Sidoarjo

Jl. Raya Rame Pilang No.4 Wonoayu, Sidoarjo, East Java, Indonesia, (Pilang Campus)

Email: jamilaturrohmah@umsida.ac.id
} 


\section{INTRODUCTION}

Indonesia is a tropical country and has geographical conditions that support the abundance of natural resources, especially in biodiversity. The high biodiversity (plants) can be used to meet daily food needs and can also be used as traditional medicine (Jiraungkoorskul and Jiraungkoorskul, 2015). People have used plants as medicine to tackle health problems since a long time ago. One of the plants that have medicinal properties is the turi plant.

The turi plant (Sesbania grandiflora (L.) Pers.) is a tree species that is often found in rural areas, which is a plant in the Fabaceae family (Cronquist and Takhtajan, 1996). All parts of these plants are beneficial for humans. During this time, the use of turi leaves by the community is still limited. Most people only use their flowers to be consumed as fresh vegetables. Evidently, the leaves and stems of the turi plant can be used as a mouthwash for cancer treatment because it has the chemical content of saponins, flavonoids, terpenoids, and tannins. The pharmacological activities of (Sesbania grandiflora (L.) Pers.) were: astringent, diuretic drug, aperient, analgesic, laxative, antipyretic, tonic in the form of poultice, antiulcer, anticancer, cardioprotective, hypoglycemic and hemolytic, antidiabetic, etc. (Dhiman, 2003; Doddola et al., 2008; Ganesan et al., 2016; Jiraungkoorskul and Jiraungkoorskul, 2015; Loganayaki et al., 2012; Mitra et al., 2007; Sreelatha et al., 2011). White turi leaves contain saponin and tannin compounds, which are efficacious as an antioxidant (Jiraungkoorskul and Jiraungkoorskul, 2015).

Free radicals are one of the causes of diseases that attack cells of the human body. Free radicals are present in the human body as a byproduct of the process of energy formation. Free radicals in small amounts are needed by the body to help white blood cells kill germs. If too much, they are able to attack healthy body cells, causing them to lose their structure and function. Cells can function poorly or die if this happens (Jena, 2012; Kunwar and Priyadarsini, 2011). Therefore we need an antioxidant compound that can contribute one or more electrons to free radicals so that free radicals can be suppressed. Antioxidants compounds are substances that can neutralize free radicals or a material that serves to prevent the body's biological system from adverse effects arising from processes or reactions that cause excessive oxidation (Almey et al., 2010).

There are two types of antioxidants: natural and synthetic antioxidants (Veeru et al., 2009). The antioxidant obtained from natural materials extraction that can capture free radicals is called as a natural antioxidant. Meanwhile, antioxidants derived from the results of chemical synthesis are called synthetic antioxidants. The use of synthetic antioxidants such as BHT, BHA, and TBHQ in various cosmetic products, drugs, food, and drinks, can provide toxic and carcinogenic effects on the human body so that efforts are made to look for natural antioxidants derived from plants (Kunwar and Priyadarsini, 2011; Veeru et al., 2009). The use of turi leaf extracts in this study as natural scavengers for free radicals is safer. There are almost no negative effects from these substances that can interfere with human health (Veeru et al., 2009).

The research of (Fitriansyah et al., 2017) showed that extracts of n-hexane, ethyl acetate, and ethanol of Sesbania sesban (L. Merr) leaves had an $\mathrm{IC}_{50}$ DPPH antioxidant activity $<50 \mu \mathrm{g} / \mathrm{mL}$ and could be classified as a very strong antioxidant. Sesbania Sesban ethanol extract has the highest total phenolic content $(5.18 \mathrm{~g} \mathrm{GAE} / 100 \mathrm{~g})$ and the highest total flavonoid content (4.56 g QE / $100 \mathrm{~g})$, while the highest total carotenoid content $(4.56 \mathrm{~g} \mathrm{BE} / 100 \mathrm{~g})$ in $\mathrm{n}$-hexane extract. The total phenolic content in the Sesbania sesban leaf extract has a significant and negative correlation with their $\mathrm{IC}_{50}$ DPPH cleaning activity. Sesbania sesban (L. Merr) plants used were obtained from Ujung Berung, Bandung, West Java, Indonesia.

Previous research conducted by Rohmah, Rachmawati and Nisak (2018) mentioned that the acetone extract of leaves and stems of white turi (Sesbania grandiflora) had an antioxidant activity with $\mathrm{IC}_{50}$ values of $56.5707 \mathrm{ppm}$ and $54.2608 \mathrm{ppm}$ and categorized as strong antioxidant based on FDA category (Molyneux, 2004). Antioxidant activity did not differ significantly between the acetone extract of leaves and stems of white turi (Sesbania grandiflora). Nevertheless, it was significantly 
different from ascorbic acid with antioxidant activity, which is included in the very strong category based on the FDA category (Molyneux, 2004). However, the right type of solvent was not found to get the highest antioxidant activity from the white turi leaves. Therefore further research is needed in order to obtain the right type of solvent to obtain antioxidant activity from white turi leaves extract by other extraction solvents with different polarity levels (ethanol, ethyl acetate, and n-hexane solvents). Because the solvent is very influential on the withdrawal of active compounds so that the use of different solvents can be known to have the highest antioxidant activity.

\section{MATERIALS AND METHOD}

Materials

The white turi leaves (Sesbania grandiflora (L.) Pers.) were obtained from Mojosari Mojokerto and determined at Lembaga Ilmu Pengetahuan Indonesia (LIPI) for Plant Conservation in the Botanical Gardens of Purwodadi, Pasuruan, East Java by the herbarium staff.

\section{Methods}

\section{Sesbania grandiflora (L.) Pers. extract preparation}

The white turi leaves were crushed and macerated using various extraction solvents $(70 \%$ ethanol, ethyl acetate, and n-hexane) for 24 hours. The amount of white turi leaves for maceration is 800 gram for each solvent in $1600 \mathrm{~mL}$ solvent (with ratio 1:2). The filtrate was collected, and the residue was soaked until colorless filtrate. Then, the collected filtrate was concentrated using a rotary vacuum evaporator at a temperature of $55^{\circ} \mathrm{C}$ to obtain concentrated extracts, and the solvent was recovered (Pal et al., 2011; Saxena et al., 2013).

\section{Qualitative phytochemical screening assay}

The white turi leaves extract in various extraction solvents phytochemical screening was conducted by referring to Tiwari et al., (2011); Banu and Cathrine, (2015):

\section{Tannins identification}

About $1 \mathrm{~mL}$ of each white turi leaves extract in various solvents heated for several minutes in the test tube. Then, a few drops of $1 \% \mathrm{FeCl}_{3}$ was added. The formation of greenish-brown or blackish purple indicates the presence of tannins.

\section{Alkaloids identification}

Around $1 \mathrm{ml}$ of each extract was added with chloroform and $\mathrm{NH}_{3}$ and heated on a water bath. One drop of $\mathrm{H}_{2} \mathrm{SO}_{4}$ was added to each test tube. The first canister was added with Mayer's reagent. The second tube was added with Wagner reagents. Meanwhile, the third tube was added with Dragendroff reagent. If white deposits formed in the first tube, orange deposits in the second tube, and brown deposits in the third tube, it indicates that the sample contains alkaloids.

\section{Flavonoids identification}

About $1 \mathrm{ml}$ of each extract was added to $3 \mathrm{~mL}$ of $70 \%$ ethanol is shaken, heated, and shaken again. Then, they were filtered, and the filtrate was taken. The filtrate was added with $0.1 \mathrm{mg}$ of powder and 3 drops of concentrated $\mathrm{HCl}$. If the brick red color is formed in the sample, it indicates the presence of flavonoid compounds.

\section{Saponins identification}

About $1 \mathrm{ml}$ of each extract was added to $10 \mathrm{~mL}$ of distilled water and boiled in a water bath. Then, the mixture is shaken and left for 15 minutes. The formation of a stable foam indicates the presence of saponin compounds. 


\section{Steroids identification}

Samples from around $1 \mathrm{~mL}$ of each extract weres added with $3 \mathrm{~mL}$ of $70 \%$ ethanol and $2 \mathrm{ml}$ of concentrated $\mathrm{H}_{2} \mathrm{SO}_{4}$ and $\mathrm{CH}_{3} \mathrm{COOH}$. The formation of a bluish-purple or greenish color indicates the presence of steroids in the sample.

\section{Triterpenoids (Liebermann-Burchard test) identification}

Around $1 \mathrm{~mL}$ of each extract was added with $2 \mathrm{~mL}$ of chloroform and $3 \mathrm{~mL}$ of concentrated $\mathrm{H}_{2} \mathrm{SO}_{4}$. The formation of a brownish-red color characterizes the positive reaction to terpenoids.

\section{Phenolic identification}

About $1 \mathrm{~mL}$ of sample was added with $1 \% \mathrm{NaCl}$ and $10 \%$ gelatin. If a white precipitate is formed, it contains a phenolic compound.

\section{Thin-layer chromatography test}

Preliminary test analysis of free radical scavengers to turi leaves extract on various extraction solvents by thin-layer chromatography (TLC). The stationary phase used in this method is silica gel $\mathrm{F}_{24}$ with a size of 60 mesh, and the mobile phase used for elution is ethyl acetate and ethanol (1:4), nhexane and ethyl acetate (4:1), and methanol, ethyl acetate, and $n$-hexane $(8: 3: 1)$, for all extracts. Small amounts of ethanol, ethyl acetate, and n-hexane extracts of turi leaves are spotted in the stationary phase, then eluted in a chamber chromatography. Next, the TLC plate was observed under a UV lamp at wavelengths of 254 and $366 \mathrm{~nm}$. The resulted spot is then marked, and the Rf value (retardation factor) is calculated.

\section{DPPH scavenger activity assay}

The free-radical scavenging effect of Sesbania grandiflora (L.) Pers. was measured with the stable radical scavenger DPPH (diphenylpicrylhydrazyl) with minor modification (Krishnaiah et al., 2011). As many as 0.01 grams of ethanol, ethyl acetate, and n-hexane extracts of white turi leaves were diluted in $100 \mathrm{ml}$ methanol. Furthermore, variations in the sample stock solution $(5,10,15,20$, and $25 \mathrm{ppm}$ ) were made. Preparation of DPPH solution was carried out by weighing 0.004 grams of DPPH crystal and diluted in $100 \mathrm{~mL}$ methanol in a volumetric flask. Next, $3 \mathrm{ml}$ of sample from each variation with different concentrations were added with $3 \mathrm{~mL}$ of DPPH $0.004 \%$. The incubation process was carried out for 30 minutes at room temperature. Then, the absorbance with a UV-Vis spectrophotometry was read at a wavelength of $517 \mathrm{~nm}$. Then, ascorbic acid (variations in the concentration of $5,10,15,20$, and $25 \mathrm{ppm}$ ) was used as a positive control. The absorbance measurement of ascorbic acid was done the same as reading the absorbance value for the sample. Each measurement was repeated 5 times. Free radical scavengers activity can be known from the results of the absorption data by calculating the following formula:

where,

$$
\text { Radical scavenging }(\%)=\left[\left(\mathrm{A}_{0}-\mathrm{A}_{1} / \mathrm{A}_{0}\right) \times 100\right] \text {. }
$$

$\mathrm{A}_{0}=$ Absorbance of the control solution (DPPH solution without sample) and $\mathrm{A}_{1}=$ Absorbance of the sample extracts (DPPH solution with sample).

\section{Statistical analysis}

The SPSS program (version 16.0) was used to carry out the statistical analysis. The DPPH scavenger assays results of each extract were analyzed using linear regression analysis. The linear regression equation generated in this process was used to determine the Median Inhibitory Concentration $50\left(\mathrm{IC}_{50}\right)$. 


\section{RESULT AND DISCUSSION}

\section{Sesbania grandiflora (L.) Pers. extract preparation}

Extraction with various solvents aims to determine free radical scavengers level with various solubility to discover the highest potential bioactivity compound (Harborne, 1992). The extract results can be seen in Table 1.

Table 1. The extract results of white turi (Sesbania grandiflora (L.) Pers.) leaves

\begin{tabular}{clccc}
\hline \multirow{2}{*}{ Sample } & \multirow{2}{*}{ Parameter } & \multicolumn{3}{c}{ Extract Results } \\
\cline { 3 - 5 } & Simplicia powder & Ethanol & Ethyl Acetate & n-Hexane \\
\hline \multirow{2}{*}{ Turi } & S00 gram & 800 gram & 800 gram \\
leaves & Concentrated extract & 83.4831 gram & 33.7974 gram & 27.426 gram \\
& Rendement & $10.44 \%$ & $4.22 \%$ & $3.43 \%$ \\
\hline
\end{tabular}

Based on Table 1, the yield percentage of white turi leaf extract in various extraction solvents was obtained. The percentage of yield is the value that shows the ratio between extracts obtained with simplicia in percent (\%) units. Extract yield was calculated by the weight of thick extract divided by initial weight (weight of simplicia) multiplied by $100 \%$ (Sani et al., 2014). The extract with the highest percentage of yield is ethanol extract. This shows that the compound content in turi leaves tends to dissolve in ethanol solvents. The difference in the yield is thought to be caused by the solubility of the metabolite in the solvent (Pratiwi et al., 2016).

\section{Qualitative phytochemical screening}

Qualitative phytochemical screening aims to identify active compounds or secondary metabolite compounds contained in the sample. Phytochemical tests carried out on the extracts of white turi leaves (Sesbania grandiflora (L.) Pers.) on various extraction solvents and test results are shown in Table 2.

Table 2. The qualitative phytochemical screening assay of white turi (Sesbania grandiflora $(\mathrm{L}$. Pers.) leaves extract

\begin{tabular}{|c|c|c|c|c|}
\hline \multirow[b]{2}{*}{$\begin{array}{c}\text { Phytochemical } \\
\text { assay }\end{array}$} & \multirow[b]{2}{*}{ Test Reagents } & \multicolumn{3}{|c|}{ Results } \\
\hline & & $\begin{array}{l}\text { ethanol } \\
\text { extract }\end{array}$ & $\begin{array}{c}\text { ethyl acetate } \\
\text { extract }\end{array}$ & $\begin{array}{c}\text { n-hexane } \\
\text { extract }\end{array}$ \\
\hline \multirow[t]{3}{*}{ Alkaloids } & Mayer & + & + & + \\
\hline & Wagner & + & + & + \\
\hline & Dragendorff & + & + & - \\
\hline Flavonoids & $\mathrm{Mg}+\mathrm{HCl}_{\text {concentrated }}+$ etanol & - & - & - \\
\hline Saponins & - & + & - & - \\
\hline Steroids & Libermann-Burchard & + & + & + \\
\hline Triterpenoids & Chloroform $+\mathrm{H}_{2} \mathrm{SO}_{4}$ concentrated & - & - & + \\
\hline Phenolics & $\mathrm{NaCl} 10 \%$ + Gelatin 1\% & + & - & - \\
\hline Tannins & $\mathrm{FeCl}_{3} 1 \%$ & + & + & + \\
\hline
\end{tabular}

(+): presence; (-): not detected

Based on the results of phytochemical screening (Table 3) on ethanol extracts of white turi leaves (Sesbania grandiflora (L.) Pers.) contains alkaloids, saponins, steroids, phenolics, and tannins. In contrast, the ethyl acetate extract of white turi leaves (Sesbania grandiflora (L.) Pers.) contains alkaloids, tannins, and steroids. The n-hexane extract of white turi leaves (Sesbania grandiflora (L.) Pers.) contains alkaloids, steroids, triterpenoids, and tannins. The difference in the content of secondary metabolites is due to polarity differences in extraction solvents used. In addition, the same compound or group of the same compound is possible to be synthesized or buried in different organs. 
The levels of different secondary metabolites will affect the analysis of free radical scavengerss (Del Baño et al., 2003).

\section{Thin-layer chromatography test}

A thin-layer chromatography test is a confirmation test from a qualitative phytochemical screening. The thin-layer chromatography test or TLC is a compound separation test based on differences in two phases: the stationary and mobile phases (Cai, 2014). The results of Thin-Layer Chromatography (TLC) tests on white turi (Sesbania grandiflora (L.) Pers.) leaves extracts are shown in Table 3 and Figure 1.

Table 3. TLC test results of white turi (Sesbania grandiflora (L.) Pers.) leaves extract on various extraction solvents

\begin{tabular}{ccc}
\hline Type of Extract & Spot Number & Rf value \\
\hline ethanol extract & 1 & 0.75 \\
& 2 & 0.89 \\
ethyl acetate extract & 1 & 0.47 \\
n-hexane extract & 2 & 0.76 \\
& 1 & 0.25 \\
& 2 & 0.39 \\
& 3 & 0.67 \\
& 4 & 0.52 \\
& 5 & 0.6 \\
& 6 & 0.73 \\
\hline
\end{tabular}

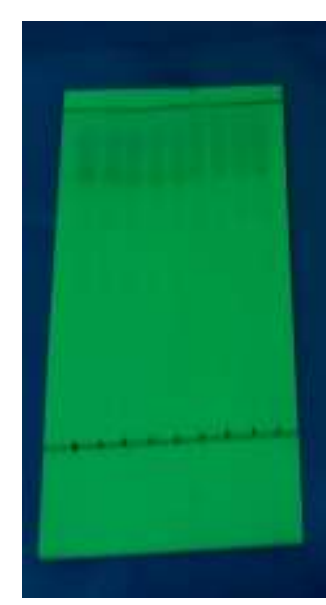

(a)

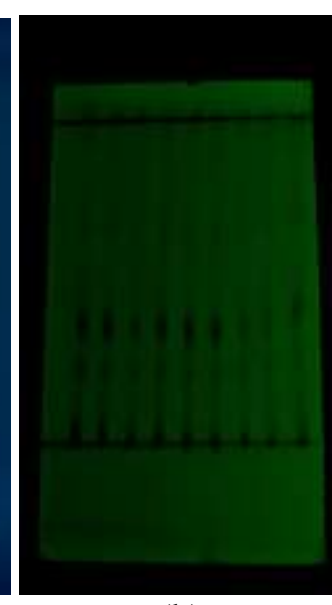

(b)

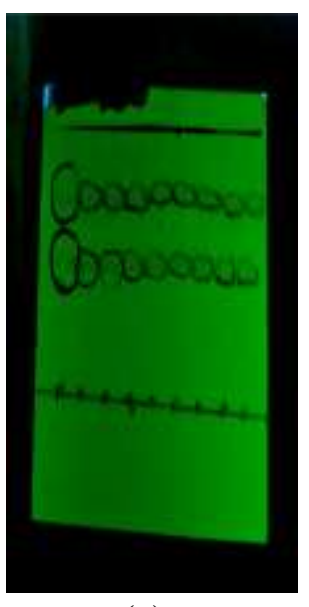

(c)

Figure 1. TLC test results of white turi extracts on UV lamp 254 nm, (a) ethanol, (b) n-hexane, and (c) ethyl acetate extract

In this study, the stationary phase used is the $\mathrm{GF}_{254}$ plate. While the mobile phase used is eluent ethanol: ethyl acetate (4: 1), which is the best eluent compared to n-hexane: ethyl acetate (4: 1), methanol: ethyl acetate: n-hexane (8: 3: 1), because no color spots are formed. Then, a spot on the plate is produced using ethanol: ethyl acetate (4: 1) eluent (Figure 1). 


\section{DPPH scavenger activity assay}

Determination of antioxidant activity in this study using the DPPH method. DPPH will have high accuracy, is inexpensive, easy, and practical (Molyneux, 2004). The reaction occurs in the antioxidant activity using the DPPH method is DPPH, which is approved with antioxidant composition to produce hydrogen atoms. The purple color of the solution will change to a bright yellow color. The free radical scavengers reaction by the DPPH method is quoted in Figure 2 as follows:

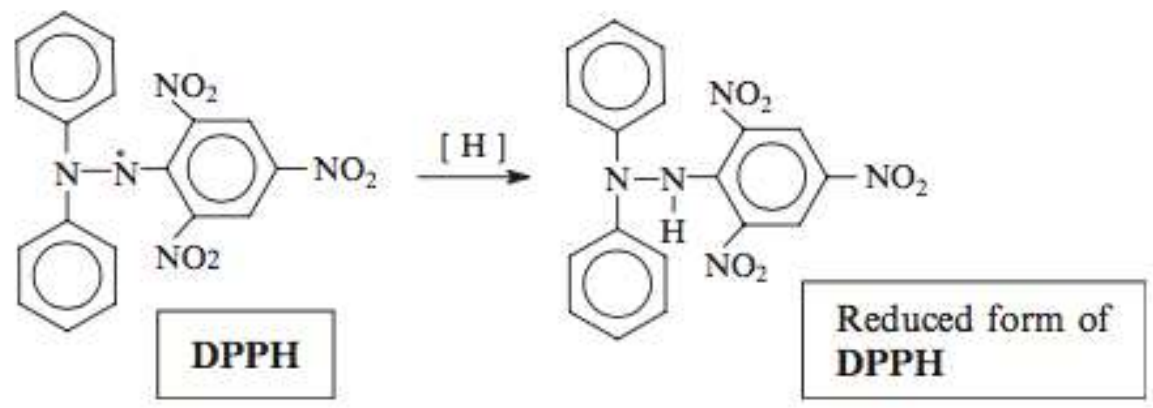

Figure 2. Reduction of DPPH radicals with antioxidants (Mani et al., 2011)

Violet color absorption was measured at a wavelength of $517 \mathrm{~nm}$ (Widowati et al., 2015). After discovering the absorbance of the free radical scavengers from ethanol, ethyl acetate, and n-hexane extracts of white turi leaves (Sesbania grandiflora (L.) Pers.), $\mathrm{IC}_{50}$ values can be determined. The $\mathrm{IC}_{50}$ value is the concentration allowed by an antioxidant to reduce 50\% of DPPH free radicals (Brody, 2018). If the $\mathrm{IC}_{50}$ value $<50 \mathrm{ppm}$, it is revealed to have a very strong antioxidant activity. The absorbance of white turi leaf extracts (Sesbania grandiflora (L.) Pers.) and ascorbic acid as positive control showed the higher concentration of white turi leaf extract and ascorbic acid, the smaller the absorbance value obtained. This is due to the higher concentration of extract and ascorbic acid, the more amount of compounds in the solution to capture free radicals (DPPH) so the purple color of DPPH solution is decreases (Kedare and Singh, 2011; Pavithra and Vadivukkarasi, 2015). Furthermore, from the absorbance results obtained, all samples' inhibition percentages were calculated and can be seen in Figure 3.

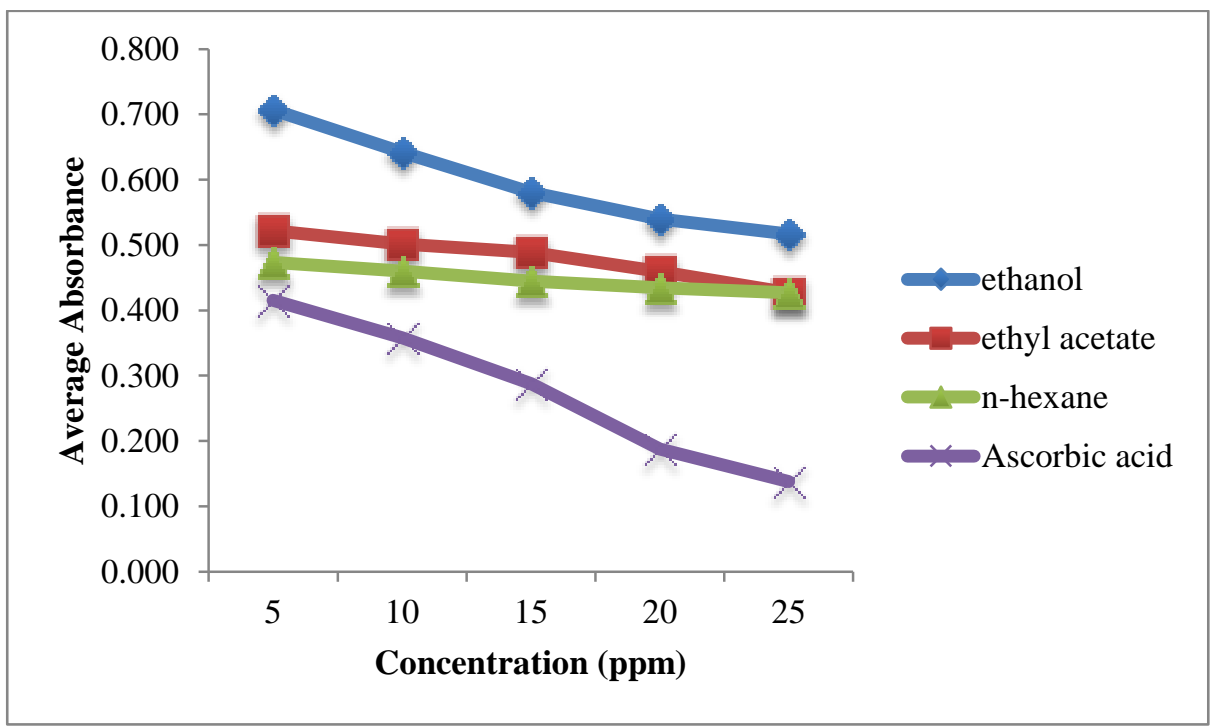

Figure 3. Absorbance of white turi leaf extracts (Sesbania grandiflora (L.) Pers.) and ascorbic acid 


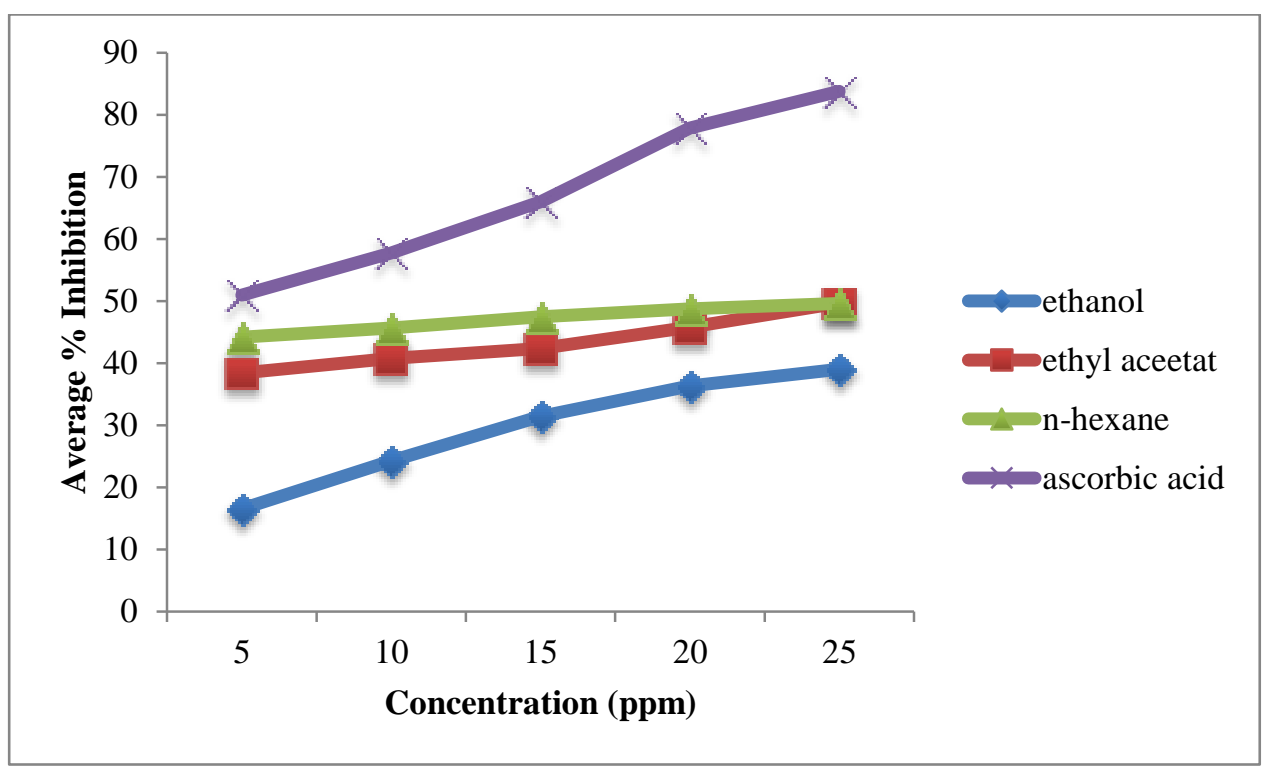

Figure 4. Percentage of inhibition of white turi leaf extracts (Sesbania grandiflora (L.) Pers.) and ascorbic acid

Figure 4 shows that the higher concentration of white turi leaves extracts and ascorbic acid, the higher the percentage of inhibition. The higher concentration caused more metabolite compounds in the extract so that the metabolite compound can donate $\mathrm{H}$ atoms to DPPH free radicals and form a more stable DPPH-H bond (Kedare and Singh, 2011; Pavithra and Vadivukkarasi, 2015). The more stable the DPPH-H bond, the less the color absorption intensity (Pratiwi et al., 2016). If the color intensity of the absorption decreases, then the absorbance will become low, so the percentage of inhibition is higher (Kedare and Singh, 2011; Pavithra and Vadivukkarasi, 2015). This can be shown in the DPPH reaction with antioxidant compounds in Figure 2. Likewise, ascorbic acid is a secondary antioxidant compound that is more stable because it has two hydrogen atoms to capture free radicals. The more DPPH-H bonds are formed, the solution will turn yellow, and ascorbic acid absorbance becomes low (Figure 3). If the absorbance is low, then the percentage of inhibition is high (Pratiwi et al., 2016). The following is the reaction of extracts and ascorbic acid in reducing free radicals (DPPH):

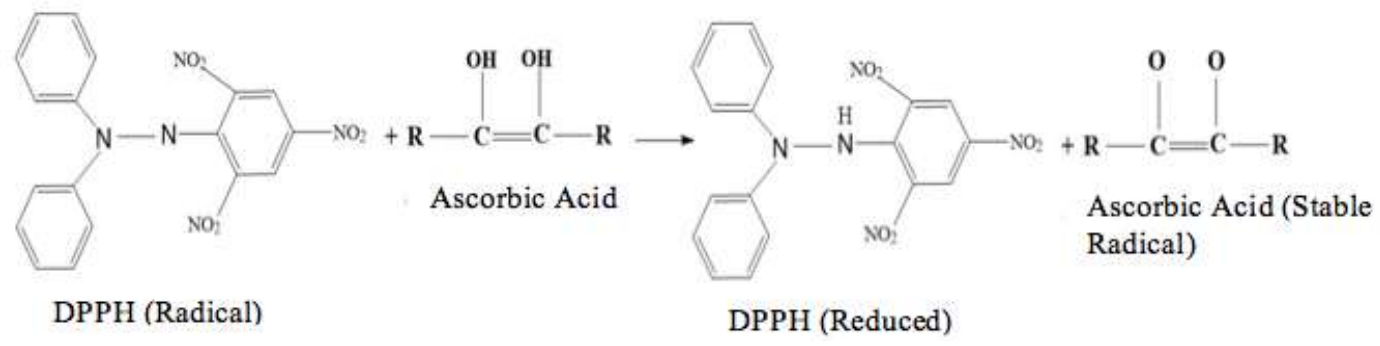

Figure 5. Reaction of ascorbic acid with DPPH (free radicals) (Mani et al., 2011) 
Ascorbic acid or vitamin $\mathrm{C}$ has very strong antioxidant activity because of ascorbic acid's more stable nature. Ascorbic acid can donate two hydrogen atoms to the DPPH free radical and form a stable L-ascorbyl radical (Figure 5) (Mani et al., 2011). Tannins have quite a powerful antioxidant activity because the stability of the structure influences them. Tannin and flavonoid compounds, which are good reducing agents, will donate $\mathrm{H}$ atoms as DPPH free radical reducer, resulting in a radical stabilization of tannin compounds. The stability of the tannin structure can also be caused by the position of the hydroxyl group in the ortho position, namely the - $\mathrm{OH}$ group attached to atom $\mathrm{C}$ number 3 and number 4 in ring B. Orthohydroxyl structure increases the antioxidant activity of tannin compounds (Chung et al., 1998).

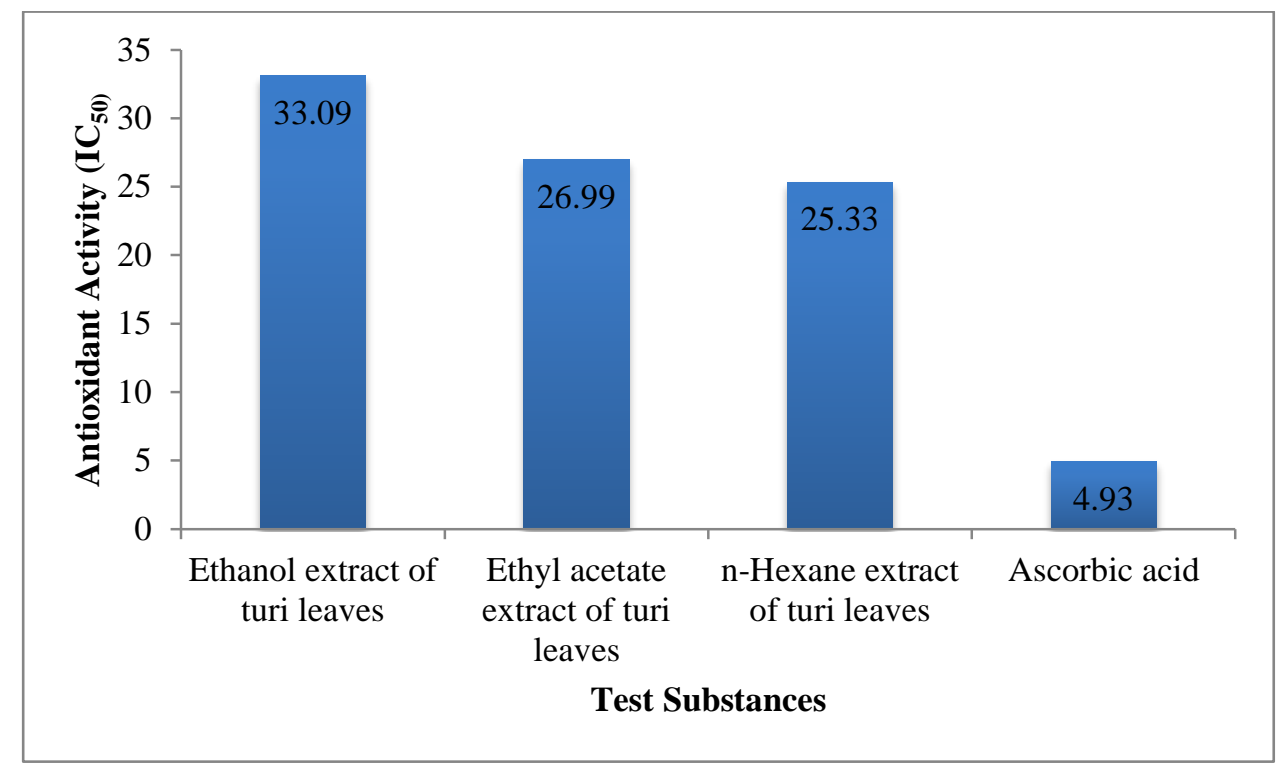

Figure 6. The $\mathrm{IC}_{50}$ value of each sample

A compound or extract's ability to inhibit an oxidation reaction that can be expressed as a percent reduction or inhibition is called an antioxidants activity. The parameter used to indicate that antioxidant activity is the value of efficient concentration $\left(\mathrm{EC}_{50}\right)$ or inhibition concentration $\left(\mathrm{IC}_{50}\right)$. Substances with high antioxidant activity will have low $\mathrm{EC}_{50}$ or $\mathrm{IC}_{50}$ value (Brody, 2018).

Figure 5 showed that the $\mathrm{IC}_{50}$ value of all three extracts had weaker antioxidant activity than ascorbic acid, although the values were categorized in a very strong activity. In Figure 5, n-hexane extract has the highest antioxidant activity compared to ethanol and ethyl acetate extracts. The order of strength of antioxidant activity is as follows: n-hexane extract > ethyl acetate extract > ethanol extract of white turi leaf. This is influenced by the content of the active compound extracted in each solvent. The ethanol extracts of white turi leaves in phytochemical tests contain alkaloid compounds, saponins, steroids, phenolics, and tannins. In contrast, ethyl acetate extract contains alkaloids, steroids, and tannins. The n-hexane extract contains alkaloids, steroids, triterpenoids, and tannins. The difference in the content of active compounds also affects the antioxidant activity of each extract. The three extracts have similarities and differences in secondary metabolites' content, which equally contains alkaloids, steroids, and tannins. Simultaneously, the differences in secondary metabolite compounds are in the saponin and phenolic compounds (in ethanol extract), and triterpenoids (in n-hexane extract).

Alkaloids in extracts are thought to provide antioxidant activity with secondary mechanisms, namely as free radical scavengers. Research conducted by (Maiza et al., 2007) supports this concerning the two fumaria species alkaloid extracts (Fumaria capreolata and Fumaria bastardii). 
It stated that the alkaloid extracts of the two Fumaria species have antioxidant activity that works by a mechanism as a free radical scavenger. Steroid compounds in extracts are thought to have a role in providing antioxidant activity. The mechanism that is played by steroids is as a radical catcher. Cui et al., (2005) supported this fact, stated that $80 \%$ ethanol extract of Inonotus obliquus is positive to contain steroids, such as lanosterol and ergosterol peroxide, producing antioxidant activity and quite active secondary radical scavenger. Moreover, tannin compounds are also thought to play a role in providing antioxidant activity. However, these tannin compounds are considered less active due to intruders such as proteins, fats, and other compounds that can bind to tannins, thus blocking the process of capturing free radicals. Protein or fat in plants can provide the hydrogen atom they have to bind with hydroxyl radicals in DPPH (Birben et al., 2012).

In ethanol extract, phenolic compounds' presence acts as an antioxidant because it has a hydroxyl group that can release protons in hydrogen ions. The hydrogen ion has only one proton and has no electrons, so the radical electron in the nitrogen atom in DPPH binds to the hydrogen ion and produces a reduced DPPH (Gurav et al., 2007). However, phenolic compounds in ethanol extracts of white turituri leaves are non-polar compounds, which still contain glycoside groups that inhibit the binding of DPPH radicals and weak antioxidants produced. Side groups that bind to phenolic can be inhibited the inhibition of antioxidant activity. This causes phenolics not to donate hydrogen and electrons to ward off free radicals about steric obstructions (Harborne, 1992). The presence of other groups in ethanol extract can also cause phenolic methylation. Conversion of the $\mathrm{H}$-atom into a methyl group $\left(-\mathrm{CH}_{3}\right)$ through a methylation reaction can reduce antioxidant activity, which in turn reverses the $\mathrm{H}$-atom, which is a source of protons to capture free radicals (Birben et al., 2012).

Whereas in $\mathrm{n}$-hexane extract, the presence of triterpenoid compounds is phenol compounds found in plants (Gurav et al., 2007). Phenol compounds can be the main determinants of food antioxidant potential (Pal et al., 2011) because, in phenol compounds, there are aromatic rings so that in triterpenoid compounds, there are also aromatic rings. The phenol compound has a $\mathrm{C}_{6}$ structure, whereas the terpenoid compound has a $\mathrm{C}_{5}$ structure (Harborne, 1992). The bioactive compound in $\mathrm{n}$ hexane extract plays an active role as an antioxidant in counteracting DPPH free radicals and can provide the highest antioxidant activity compared to ethanol and ethyl acetate extracts. However, it is still in a very strong antioxidant activity.

Nevertheless, the various compounds contained are thought to cause synergism to make antioxidants in the stable white turi leaf extract. This can be supported from previous studies conducted by Rohmah et al., (2018) on acetone extract of leaves and stems of white Turi (Sesbania grandiflora) have antioxidant power with $\mathrm{IC}_{50}$ values of $56.5707 \mathrm{ppm}$ and $54.2608 \mathrm{ppm}$. Besides, the type of yellow Turi, namely ethanol extract of yellow Turi leaf, has antioxidant power with an $\mathrm{IC}_{50}$ value of $4.12 \mathrm{ppm}$ (Fitriansyah et al., 2017). Likewise, Sesbania sesban leaves extracts with different polarity solvents ( $n$-hexane extract, ethyl acetate extract and ethanol extract) can be categorized as very strong antioxidant. The highest total phenolic and flavonoid content was showed by ethanol extract, whereas the highest total carotenoid content was given by n-hexane extract. Total phenolic content in Sesbania sesban leaves extracts had a significant and negative correlation with their $\mathrm{IC}_{50}$ of DPPH scavenging activities. The difference in $\mathrm{IC}_{50}$ values can be influenced by the number of secondary metabolite compounds in turi plants and the polarity of the solvents used. However, the content of secondary metabolites in turi plants is also influenced by environmental conditions surrounding trees' growth, such as temperature, humidity, sunlight, soil fertility, and threats.

\section{CONCLUSION}

The white turi (Sesbania grandiflora (L.) Pers.) leaves extracts in various extraction solvents have antioxidant activities In the order of strength of antioxidant activity as follows: n-hexane extract $>$ ethyl acetate extract > ethanol extract. The white turi plant (leaves) can be one of the natural sources of antioxidants to prevent diseases caused by free radicals. 


\section{ACKNOWLEDGEMENT}

The authors would like to acknowledge the Universitas Muhammadiyah Sidoarjo for funding this research; Laboratory of Medical Laboratory Technology Umsida and Laboratory of Organic Chemistry UNESA for supporting the methodology and laboratory facilities used in the research, and those who helped carry out the research.

\section{REFERENCES}

Almey, A., Khan, A.J., Zahir S., Suleiman M., Aisyah Rahim K., 2010. Total phenolic content and primary antioxidan activity of methanolic and ethanolic extract of aromatic 'plants' leaves. International Food Research Journal. 17 : 1077-88.

Banu, K.S., Cathrine, L.. General techniques involved in Phytochemical analysis. International Journal of Advanced Research in Chemical Science. 2015; 2(4):25-32.

Birben, E., Sahiner, U.M., Sackesen, C., Erzurum, S., Kalayci, O., 2012, Oxidative Stress and Antioxidant Defense, World Allergy Organ Journal., 5(1): 9-19.

Brody, T., 2018, Drug Class Analysis. 'FDA's Drug Review Process and the Package Label, 441-511.

Cai, L., 2014, Thin Layer Chromatography, Division of Mathematics and Science, University of South Carolina Salkehatchie, Walterboro, South Carolina.

Chung, K.T., Wong, T.Y., Wei, C.I., Huang, Y.W., \& Lin, Y., 2010. Tannins and Human Health: A Review. Critical Reviews in Food Science and Nutrition, 38(6), 421-464.

Cronquist, A., Takhtajan, A., 1996, An integrated system of classification of flowering plants, New York, Columbia University Press, 477.

Cui, Y., Kim, D.S., dan Park, K.C. 2004. Antioxidant Effect Inonotus obliquus. Journal of Etnopharmacol. 79-85.

Del Bano, M.J., Lorente, J., Castillo, J., Garcia, O.B., Del Rio, J.A., Ortuno, A., Quirin, K.W., and Gerard, D., 2003, Phenolic diterpenes, flavones, and rosmarinic acid distribution during the development of leaves, flowers, stems, and roots of rosmarinus officinalis, Antioxidant Activity, Journal of Agricultural and Food Chemistry, 51, 15, 4247-4253.

Dhiman, A.K., 2003, Sacred plants and their medicinal uses. Daya publishing house Delhi, 172.

Doddola, S., Pasupulati, H., Koganti, B., Prasad, K.V.S.R.G., Evaluation of Sesbania grandiflora for antiurolithiatic and antioxidant properties. Journal of Natural Medicines. 2008; 62(3):300-3007.

Fitriansyah, S.N., Fidrianny, I., Ruslan, K. 2017. Correlation of total phenolic, flavonoid and carotenoid content of sesbania sesban (1. merr) leaves extract with DPPH scavenging activities. International Journal of Pharmacognosy and Phytochemical Research, 9(1), 89-94.

Ganesan, K., Nair, S.K.P., Sinaga, M., Gani, S.B., 2016. A review on the phytoconstituents and pharmacological actions in the medicinal plants of Bedabuna forest, Jimma Zone, South West Ethiopia Reported Effect on Experimental Models. European Journal of Biomedical AND Pharmaceutical sciences, 3(1):62-83.

Gurav, S., Deshkar, N., Gulkari, V., Duragkar, N., Patil, A, 2007. Free radical scavenging activity of Polygala chinensis Linn. Pharmacology,2: 245-253.

Harborne, J.B. 1992. Phytochemical methods, a guide to modern techniques of plant analysis. London, New York: Chapman and Hall.

Jena, N.R. 2012. DNA damage by reactive species: Mechanisms, mutation and repair. Journal of Biosciences. 37(3) : 503-17.

Jiraungkoorskul, K., and Jiraungkoorskul, W., 2015, Sesbania grandiflora: new nutraceutical use as antidiabetic. International Journal of Pharmacy and Pharmaceutical Sciences ,7(7): 26-29.

Kedare, S.B., and Singh, R.P., 2011, Genesis and development of DPPH method of antioxidant assay, Journal of Food Science and Technology, 48: 412-422.

Krishnaiah, D., Sarbatly, R., Nithyanandam, R., 2011, A review of the antioxidant potential of medicinal plant species. Food Bioprod Process. 89(3):217-33.

Kunwar, A., and Priyadarsini K.I.. 2011, Free Radicals, oxidatives stress and importance of antioksidants in human health. Journal of Medical and Allied Sciences, 1(2): 53-60. India. 
Loganayaki, N., Suganya, N., Manian, S., Evaluation of edible flowers of agathi (Sesbania grandiflora L. Fabaceae) for in vivo anti-inflammatory and analgesic, and in vitro antioxidant potential. Food Science and Biotechnology, 2012; 21(2):509-17.

Mani, R.P., Awanish, P., Shambaditya, G., Poonam, T., Kumudhavalli, V., Pratap, S.S., 2011, Phytochemical screening and in-vitro evaluation of antioxidant activity and antimicrobial activity of the leaves of Sesbania sesban (L.) Merr. Free Radicals and Antioxidants, 1, (3);66-69

Maiza-Benabdesselam, F., Khentache, S., Bougoffa, K., Chibane, M., Adach, S., Chapeleur, Y., Max, H, 2007. Antioxidant activities of alkaloid extract of two algerian species of Fumaria: Fumariacapreolata and Fumariabastardii. Records of Natural Products.1, 28-35.

Mitra, R., Mitchell, B., Gray, C., Orbell, J., Coulepis, T., Muralitharan, M.S., 2007, Medicinal plants of Indonesia, APBN, 11, 11. 726-743.

Molyneux, P., 2004, The use of the stable free radical diphenylpicrylhydrazyl (DPPH) for estimating antioxidant activity. Songklanakarin Journal of Science and Technology, 26(2), 211-219.

Pal, R., Girhepunje, K., Shrivastav, N., Hussain, M.M., 2011, Antioxidant and free radical scavenging activity of ethanolic extract of Morinda citrifolia. Library (Lond). 2(1):127-31.

Pavithra, K., and Vadivukkarasi, S., 2015, Evaluation of free radical scavenging activity of various leaf extracts from Kedrostis foetidissima (Jacq.) Cogn, Biochemistry and Analytical Biochemistry, 3(2):1.

Pradeesh, S., Swapna, T.S., 2018, Antioxidant Activity in Leaves of Sesbania Grandiflora (L.) Pers. Asian Journal of Pharmaceutical and Clinical Research, Vol 11, Issue 1.

Pratiwi, L., Fudholi, A., Martien, R., Pramono, S., 2016, Ethanol extract, ethyl acetate extract, ethyl acetate fraction, and n-heksan fraction mangosteen peels (Garcinia mangostana L.) as source of bioactive substance free-radical scavengers, Journal of Pharmaceutical Science and Clinical Research, 01, 71-82.

Rohmah, J., Rachmawati, N.R., Nisak, S., 2018, Perbandingan daya antioksidan ekstrak aseton daun dan batang turi putih (Sesbania Grandiflora) dengan metode DPPH (diphenylpycrylhydrazyl). Prosiding Seminar Nasional Hasil Riset dan Pengabdian (SNHRP-I). 665-675.

Sani, R.N., Fithri C.N., Ria D.A., dan Jaya M.M. 2014. Analisis rendemen dan skrining fitokimia ekstrak etanol mikroalga laut Tetraselmis chuii. Jurnal Pangan dan Agroindustri. 2(2):121-126.

Saxena, M., Saxena, J., Nema, R., Singh, D., Gupta, A., Phytochemistry of medicinal plants. Journal of pharmacognosy and phytochemistry. 2013; 1(6):168-182.

Shyamala, S.G., and Vasantha, K., 2010, Antioxidant activity of Sesbania grandiflora (pink variety) L. Pers. International Journal of Engineering Science and Technology, Vol. 2(9), 2010, 4350-4356.

Sreelatha, S., Padma, P.R., Umasankari, E., 2011, Evaluation of anticancer activity of ethanol extract of Sesbania grandiflora (Agati Sesban) against Ehrlich ascites carcinoma in Swiss albino mice. Journal of Ethnopharmacology. 2011; 134(3):984-7.

Tiwari, P., Kumar, B., Kaur, M., Kaur, G., Kaur, H., 2011, Phytochemical screening and extraction: A review. Internationale Pharmaceutica Sciencia. 1(1):98- 106.

Veeru, P., Kishor, M.P., Meenakshi, M., 2009. Screening of Medicinal Plant Extracts for Antioxidant Activity. Journal of Medicinal Plant Research. 3: 8-12.

Widowati, W., Herlina, T., Ratnawati, H., Constantia, G., Deva, I.D.G.S. and Maesaroh, M., 2015, Antioxidant potential of black, green and oolong tea methanol extracts., Biology, Medicine, \& Natural Product Chemistry, 4(2): 35-39. 